\title{
Reinforcing a barrier - a specific social defense of the dwarf honeybee (Apis florea) released by the weaver ant (Oecophylla smaragdina $)^{1}$
}

\author{
Orawan DuANGPHAKDEE ${ }^{\mathrm{a}}$, Nikolaus KOENIGER ${ }^{\mathrm{b} *}$, Gudrun KOENIGER ${ }^{\mathrm{b}}$, \\ Siriwat WONGSIRI ${ }^{\mathrm{a}}$, Sureerat DEOWANISH ${ }^{\mathrm{a}}$ \\ a Center of Excellence in Entomology: Bee Biology, Biodiversity of Insects and Mites, Department of Biology, \\ Faculty of Science, Chulalongkorn University, Bangkok 10330, Thailand \\ b Institut für Bienenkunde (Polytechnische Gesellschaft), Fachbereich Biologie und Informatik \\ der J.W. Goethe-Universität Frankfurt am Main, Karl-von-Frisch-Weg 2, 61440 Oberursel, Germany
}

Received 23 November 2004 - revised 17 January 2005 - accepted 17 January 2005

Published online 13 September 2005

\begin{abstract}
In the arboreal habitat of Apis florea one of the dominant insectivorous predators is the weaver ant, Oecophylla smaragdina. The main mechanism of A. florea to protect its nest against ants and other crawling arthropods are "barriers" of sticky material (sticky bands) which the bees build around the branches and all structures which connect the comb to the outside. We studied whether the presentation of an $O$. smaragdina ant on the comb releases a specific behavioral response of the bees. After the exposure of a living $O$. smaragdina worker, held by a forceps on the top of the $A$. florea comb, the number of bees at the sticky band zone increased and remained on higher level for 2 hours compared to control experiments (presentation of an empty forceps, Tenebrio molitor larva or another arboreal ant species, Crematogaster rogenhoferi). Further, more sticky material was deposited by the bees after exposure of a weaver ant. This behavior seems to be a specific reaction of $A$. florea to its most important predator $O$. smaragdina .
\end{abstract}

Apis florea / Oecophylla smaragdina / colony defense / predator-prey relationship / Crematogaster rogenhoferi

\section{INTRODUCTION}

Apisflorea Fabricius is widespread throughout Asia, where it builds its single comb around small branches of bushes and shrubs (Akratanakul, 1977). The exposed position of the comb with the honey storage, bees and brood attracts a range of predatory species, so it is not surprising that $A$. florea posses a wide array of specific social defence mechanisms among which shimmering (Butler, 1954; Pirk et al., 2002) and hissing are most conspicuous. Shimmering behaviour is released by optical stimuli and for example a butterfly - apparently attracted by the odour of honey - releases "shimmering behaviour" (a specific movement) of a few bees hanging in the curtain and which otherwise does not interfere with colony activities. Hissing behaviour is released by mechanical stimuli or by "piping" of forager bees disturbed on their return to the nest (Sen Sarma et al., 2002). Hissing alerts the whole colony and results in steep decrease of foraging activities. The hissing sound per se may repel mammals and even large Asian bears (Koeniger and Fuchs, 1973) or initiate a full stinging defence of the colony (Koeniger and Fuchs, 1975).

A different permanent threat in the arboreal habitat of $A$. florea is posed by the weaver ant Oecophylla smaragdina (Hölldobler and Wilson, 1983), which ranks among the most important predators of A. florea (Seeley, 1983).

* Corresponding author: bienenkunde@em.uni-frankfurt.de

${ }^{1}$ Manuscript editor: Stan Schneider 
In direct fighting, the $A$. florea workers, because of their diminutive size, are no match for the large weaver ants. Colonies rely instead on sticky bands of plant resins plastered around the branch carrying the nest. Thus the comb with the brood, the honey storage and the bees are sealed off completely by sticky barriers on all structures connecting to other parts of the canopy. In a survey in northern Thailand, Seeley et al. (1982) examined 76 A. florea colonies. Only 28 of them had sticky bands, but 24 of those were under ant attack. This indicated a strong correlation between sticky bands and the presence of ants. Experimental data on the question how the presence of Oecophylla smaragdina ants is related to A. florea's construction of sticky bands are not yet available.

In our experiments we provoked $A$. florea colonies by exposing a weaver ant on the top of the colony and observed the reaction of the bees in regard to the sticky band. In comparison to the weaver ant the reaction after presentation of an empty forceps, a Tenebrio molitor larva and another arboreal ant species (Crematogaster rogenhoferi Mayr) was recorded. Our aim was to assess whether the presence of a weaver ant inside the barriers of the sticky bands causes an immediate and specific social response of $A$. florea colonies.

\section{MATERIALS AND METHODS}

\subsection{The bees}

Observations and experiments were conducted at the campus of Chulalongkorn University (Bangkok) in March to August, 2003 and in January to April 2004.

Eighteen colonies of $A$. florea were collected in a coconut estate near Maeklong, Samut Songkram Province. The A. florea nests were detected in shrubs and trees at heights of $3 \mathrm{~m}$ to $5 \mathrm{~m}$. Climbing up smoothly during day time the colony was gently smoked and afterwards sprayed with water. Surrounding leaves and twigs were carefully removed. Finally both sides of the nest branch were smoothly removed by sharp garden cutter. The colony was hung at one end of the nest branch and was brought down avoiding accelerations and jerks. Both ends of the nesting branch were tightly fixed in a wooden box for transportation to Bangkok. There, the colonies were hanged on small trees in front of the entomology laboratory (in CU campus) maintaining the vertical position of the comb. The bees started for- aging pollen and nectar at the new location. Additionally, we offered $50 \mathrm{~g}$ candy (icing sugar mixed with honey) daily on the top of the comb.

\subsection{The ants}

O. smaragdina was also collected at Maeklong. We selected a fairly large $(40 \mathrm{~cm} \times 30 \mathrm{~cm})$ leaf nest in a Mango tree and carefully clipped the surrounding twigs leaving only the branch with the nest. After the ants had calmed down and the main force of them had returned into the nest again $(15 \mathrm{~min})$ we cut the nesting branch and swiftly put the nest into a transport box which was closed immediately. In front of the entomology laboratory we fixed the $O$. smaragdina nest to a small potten Mango tree. The pot of this tree was kept in container filled with detergent water to prevent ants from escaping. The ants were fed with $10 \mathrm{~g}$ of $T$. molitor (Coleoptera: Tenebrionidae) larvae, $5 \mathrm{~g}$ of tinned mackerel fish and $10 \mathrm{~mL}$ of honey syrup per day.

\section{Presentation of different objects to the A. florea colony}

An $O$. smaragdina forager was collected from the feeding dish of the ant nest. A C. rogenhoferi worker was caught from a foraging path at a nearby tree. We held the ant by a forceps at its petiolus and put it for $1 \mathrm{~min}$ at the center of the top of the A. florea comb. Further a T. molitor larva of about $1.5 \mathrm{~cm}$ length was presented to the colony at a similar position also for $1 \mathrm{~min}$. As a control we took an empty forceps and left it also for $1 \mathrm{~min}$ on the florea comb.

\subsection{Number of bees in sticky band zone}

As a parameter for the colony reaction we counted the bees present in the sticky band zone, which was the surface of the nest branch extending from where the branch protruded from the comb to a distance of $4 \mathrm{~cm}$. We counted the number of bees at each colony 5 minutes before the presentation of the ant (see below), directly after (within 2 minutes), 1 hour after and 2 hours later each count was repeated 5 times at each of the sticky bands. We took the mean of the counts for further analysis. Our observation position was $50 \mathrm{~cm}$ away and was maintained constant for every colony.

\subsection{Deposition of material in sticky band zone}

A double layer of plastic bands (Prihimo, made in Japan) of known weight were fixed in the sticky zone. After 2 hours they were carefully removed. Because of the inner layer's contamination by some 
sticky materials that were present before the experiment, only the outer layers were used to calculate the weight of the newly deposited materials from increased weight of the band, determined by an $0.001 \mathrm{mg}$ accuracy balance (Sartorius CP2245).

\section{RESULTS}

\subsection{Behavior of bees towards different objects presented on the upper side of the comb}

The reaction of the bees towards the $O$. smaragdina worker held in the forceps happened without delay. The bees shied away from the ant and formed - head towards the ant - a multi layered wall around it. The distance to the ant was $4-7 \mathrm{~cm}$. At the same time, many bees from the comb rushed on the upper side joining the group of defending workers. After half a minute some worker bees launched counter attacks against the ant. The attacking bee seized the antenna or a leg of the ant by mandibles and tried to fly off with it. Since the ant was held by the forceps the bee did not succeed at carrying the ant away. In some cases at the end of the 1 min exposure period more bees joined the attack and stinging behavior occurred. Regularly, when we removed the ant, a few bees were attached by their mandibles to the ant so tightly that they were removed together with the ant from the comb. At the end, after we had released the ant from the forceps at the ant arena the bees let the ant go and flew back to the colony which was about $2 \mathrm{~m}$ away.

The reaction of the bees to a worker of $C$. rogenhoferi or a larva of $T$. molitor were limited to the group of bees which came into direct contact or which happened to be within a narrow range of it. The bees turned the head toward to the ant or mealworm immediately. With 3 to $5 \mathrm{~s}$ after presentation, a few bees attacked by biting and stinging. In comparison to the behavior released by a weaver ant, the reaction was different. While at least 2050 bees responded to $O$. smaragdina not more than 5-15 bees attacked $C$. rogenhoferi or T. molitor larva. In addition, we did not notice bees from the comb rushing up and joining the defense. In summary, the reaction of the A. florea colony to presentation of $C$. rogenhoferi or $T$. molitor remained locally restricted while the response released by an $O$. smaragdina worker spread over the whole colony or at least a large part of it.

An "empty" forceps did not increase the activity level on the comb. The bees moved towards to forceps and started "head-pushing" behavior (Sen Sarma et al., 2000). In a few experiments one or two bees bit the tip of the forceps with the mandibles. The relatively low level of activity caused by the empty forceps was strikingly different from the "excitement" and fast movements released by an $O$. smaragdina worker.

\subsection{Number of bees at the sticky band zone}

Under our experimental conditions $O$. smaragdina workers had no access to the $A$. florea colonies and we did not observe much activity at sticky band zones. In several scans not even a single bee was detected. On average we found $2.3 \pm 1.3$ bees ( $n=24$ observations). The bees remained motionless facing outside for a few minutes until they turned around and disappeared in curtain covering the comb. One minute after presenting a $O$. smaragdina worker on the comb the number of bees at the sticky band zone increased by a factor of $15.2 \pm 7.5$. The relative increase of bees was 7.5 after $1 \mathrm{~h}$ and $5.62 \mathrm{~h}$ after the presentation of $O$. smaragdina. The difference compared to the control (empty forceps) was highly significant (Wilcoxon, $P<$ 0.0005) after one minute (Fig. 1). Even after $2 \mathrm{~h}$ the relative increase was still significant (Wilcoxon, $P<0.001$ ). However the number of bees decreased significantly between $1 \mathrm{~min}$ and $1 \mathrm{~h}$ after the ant stimulus was presented (Wilcoxon, $P<0.002$ ). The difference between $1 \mathrm{~h}$ and $2 \mathrm{~h}$ was not significant (Wilcoxon, $P<0.122)$.

In control colonies, 1 min after presentation of a Crematogaster worker, a Tenebrio larva or of an empty forceps on the comb, we did not observe an increase of bees in the sticky band zone (Fig. 1). Apparently the increase of bees was a specific reaction to $O$. smaragdina.

\subsection{Behavior at sticky band after presentation of $\boldsymbol{O}$. smaragdina}

Ant presentation on the comb resulted first in enforcement of the guard bees at the comb 


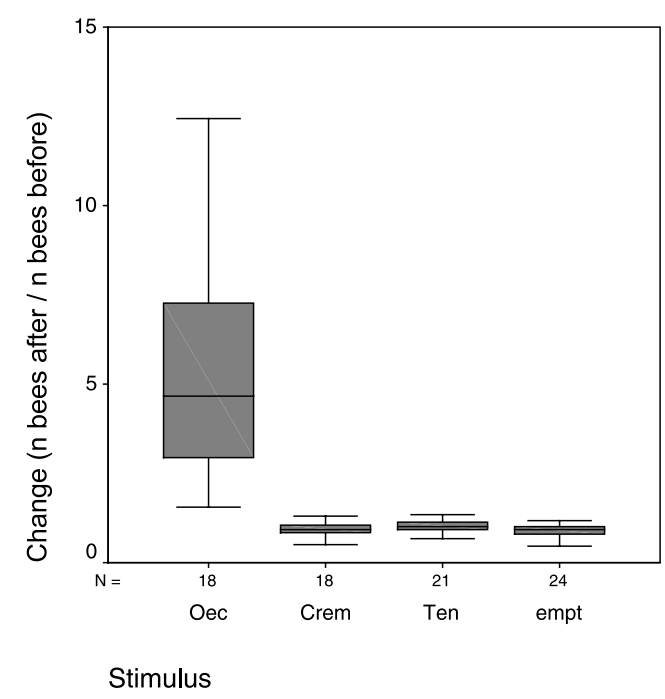

Figure 1. Increase of bees at the sticky band zone 1 minute after stimulation.

Y axis: boxplot of bee numbers divided by number of bees before the experiment.

$\mathrm{X}$ axis: Stimulus $=$ presentation of

Oec $=$ Oecophylla smaragdina forager,

Crem $=$ Crematogaster $r$.

Ten = Tenebrio molitor larva,

empt $=$ empty forceps,

on the top of Apis florea comb.

side of the sticky bands. A large group of densely packed bees $(n=12-25)$ settled with their heads towards the sticky band in a 2 or 3 fold layer. Looking along the branch over the sticky band towards the comb we saw two or three rows of worker bee heads, comparable to bricks in a wall. A small number of bees went beyond these guard bees and started to "work" on the sticky band. These bees continuously scraped the surface of the branch by their mandibles. The antennae were constantly moving back and forth. The tips of both antennae touched the surface and/or the mandibles and then swung back. The movements looked similar to the behavior of A. mellifera workers sealing wooden surfaces inside the hive with propolis (Meyer, 1954). The work on the sticky band went on for 3 to $10 \mathrm{~min}$. Then the bees (when we succeeded in keeping track of them) moved on to the comb and returned within 1 or 2 min and to continue working at the sticky band.

We did not see bees carrying material in the pollen baskets to the sticky band. Further, we did not notice that any larger particles were brought by the mandibles. However, we could not watch the head of these bees constantly during their excursions on the combs. As soon as the bee reached the nest it dived into the layer of bees. So we can not exclude that the bees did collect some smaller parts of material from the comb and fixed this to the sticky band.

\subsection{Depositions in sticky band zone}

On average the increased weight of deposits on the plastic band after ant exposure was $2.7 \mathrm{mg}$ with a standard deviation of \pm 2.73 (6 colonies, 18 experiments). In the control colonies (without ant presentation) we measured a mean of $1.4 \mathrm{mg} \pm 0.91 \mathrm{mg}$. The difference was highly significant (Mann-Whitney; $P=0.0005$ ) while there was no difference within the control group. So the presentation of an O. smaragdina worker on the colony resulted not only increasing numbers of bees but also in a larger amount of deposited material.

\section{DISCUSSION}

The use of sticky or repellent barriers to protect colonies against ants is wide spread among different taxonomic groups of social insects. In several species of social wasps (Polistinae and Stenogastrinae) the pedicel, by which the nest is fixed to substrate, is regularly impregnated by repellent pheromones from sternal glands (Espelie et al., 1994). The nest entrance of many species of Meliponinae consists of a tube built out of plant resins and sticky materials (Wilson, 1971). So the "invention" of barriers against crawling arthropods has arisen independently several times during evolution.

Generally, the nest branch is the only surface connection of the A. flore a comb to the "outside world" and it disembogues just under the platform into the comb. This platform serves as location of the bee dances and functions as an information center of the foragers (Lindauer, 1956; Koeniger et al., 1982; Seeley, 1985; Dyer, 1985).

At the platform the bees must deal with mainly two different kind of interferences. Old leaves or debris from the higher portion of the vegetation will fall on the platform and are 
removed by the recently described "head pushing" (Sen Sarma et al., 2000). We observed this behavior when we put the empty forceps on the platform. So bees "classified" the forceps alone as "debris". Afterwards we did not notice any increase of activity at the sticky bands.

The second kind of interferences which must be expected at the upper side of comb comes from crawling arthropods or other intruders which succeed in surpassing the sticky band. When we presented the forceps with the $O$. smaragdina worker we saw the latter kind of defensive behavior. The direct reactions of the bees to the ant were aimed to expel the intruder. Though the reactions to $C$. rogenhoferi or $T$. molitor involved fewer bees their intention to remove the presented insects was obvious. Presentation of C. rogenhoferi or T. molitor did not result in increasing numbers of bees working at the sticky bands. Interestingly, the significant long term effects were restricted to the presentation O. smaragdina: The "effect" of this behavior is clear. Increasing the number of guard bees and reinforcing the sticky band were means of precaution and would enable the colony to more effectively repel further intruders.

The weaver ant $O$. smaragdina is a dominant species in areas where $A$. florea occurs (Hölldobler and Wilson, 1990). Their efficient recruitment system enables weaver ants to fast communal foraging and to large prey items (Hölldobler, 1983). Therefore the existence and survival of an A. florea colony within the territory of $O$. smaragdina depends on an effective protective system. A main requirement of such defense against $O$. smaragdina is to prevent any foraging success of a weaver ant scout. As we have witnessed several times, an odor trail of a successful scout ant can recruit larger numbers of ants which will overpower defending bees and cause absconding of the colony (Wongsiri, 1989). At the end of such raids, the honey storage, the brood and quite a number of worker bees will lost to the weaver ants.

The reinforcement of the sticky barriers seems to be a specific behavioral response of A. flore a to its most prominent predator O. smaragdina. A comparable phenomenon termed enemy specification (Wilson, 1975) is known to operate between several ant species. These species recognize their most dangerous adversary species and fight against them without delay by specific mass attacks (Hölldobler, 1983).

The question of how A. flore a recognizes the weaver ant remains open. The experiments, however, with $C$. rogenhoferi and larvae of Tenebrio point to possible cues or semiochemicals specific to $O$. smaragdina.

\section{ACKNOWLEDGEMENTS}

Chariya Lekprayoon (head of entomology laboratory, Chulalongkorn Univ) shared her facilities during several weeks with Gudrun Koeniger and Nikolaus Koeniger and supported us generously. We acknowledge her significant assistance. We thank the Thailand Research Fund for financial support through Royal Golden Jubilee project. Thanks to Mr. Yhon Nonchan for collecting A. florea and $O$. smaragdina nests and Miss Mananya Phiancharoen for her kind help. We thank Ulrich Maschwitz and Stefan Fuchs for valuable suggestions and improvements of earlier versions of the manuscript.

Résumé - Renforcement d'une barrière - une défense sociale spécifique de l'Abeille naine (Apis florea) déclenchée par la Fourmi tisserande Oecophylla smaragdina. L'Abeille naine, Apis florea Fabricius, largement répandue en Asie, construit son unique rayon à l'air libre, suspendu dans des buissons, des arbustes ou des arbres. Dans cet habitat le principal prédateur insectivore est la Fourmi tisserande Oecophylla smaragdina Fabricius. Confrontées individuellement à cette fourmi de grande taille, les petites ouvrières d'A. florea ont le dessous. Par contre les colonies se protègent par des bandes collantes, à base de résines de plantes, qui entourent la branche à laquelle est accroché le nid. Le rayon est ainsi complètement barricadé par ces ceintures-pièges et isolé de toutes les structures qui le relient aux autres parties de la canopée. Lors d'une étude dans le nord du Vietnam, Seeley et al. (1982) examinèrent 76 colonies d'A. florea. Seules 28 d'entre elles possédaient des ceintures-pièges, mais 24 de celles-ci étaient attaquées par les fourmis, ce qui indique une forte corrélation entre les ceintures-pièges et la présence de fourmis. On ne sait pas à l'heure actuelle de quelle façon la présence d'O. smaragdina agit sur la construction de ceintures-pièges par $A$. florea.

Nos expériences ont consisté à provoquer une colonie d'A. florea en présentant une fourmi tisserande maintenue dans une pince au-dessus d'elle et en observant les réactions des abeilles. Le nombre d'abeilles présentes près des ceintures-pièges et l'augmentation du poids de résine ont été déterminés. Les mêmes observations ont été faites avec un ver de farine (larve de Tenebrio molitor) et une autre espèce de fourmi arboricole (Crematogaster rogenhoferi) à titre de témoin. 
Suite à la présentation d'une ouvrière vivante d' $O$. smaragdina au sommet du rayon d'A. florea, le nombre d'abeilles près de la ceinture-piège a augmenté de façon significative par rapport aux témoins (Fig. 1). Il est resté à ce niveau élevé durant $2 \mathrm{~h}$. Le matériel collant a lui aussi augmenté significativement. Le renforcement des ceintures-pièges semble être une réaction comportementale spécifique d'A. florea à son prédateur principal. Des comportements comparables, désignés par Wilson (1975) par le terme de spécification de l'ennemi, ont été décrits pour plusieurs espèces de fourmis. Ces espèces reconnaissent leur adversaire le plus dangereux et déclenchent immédiatement leur défense par des attaques massives spécifiques contre lui (Hölldobler, 1983). La question de savoir comment A. florea reconnaît la Fourmi tisserande reste ouverte. Les expériences avec $C$. rogenhoferi et les larves de $T$. molitor laissent supposer qu'il s'agit de composés sémiochimiques spécifiques à $O$. smaragdina .

Apis florea / Oecophylla smaragdina / défense de la colonie / relation prédateur-proie / Crematogaster rogenhoferi

Zusammenfassung - Verstärkung einer Barriere, - eine spezifische soziale Verteidigung der Zwerghonigbiene (Apis florea), ausgelöst durch die Weberameise (Oecophylla smaragdina). Die Zwerghonigbiene Apis florea Fabricius ist in Südasien weit verbreitet, wo sie ihre einzige Wabe frei hängend an Ästen von Büschen, Unterholz und Bäumen baut. In diesem Lebensraum ist die Weberameise Oecophylla smaragdina Fabricius ein dominanter Räuber von Insekten. In einer direkten Konfrontation mit dieser großen räuberischen Ameise ist die einzelne Apis florea Biene unterlegen. Die Bienenvölker dagegen schützen sich mit Leimringen aus Pflanzenharzen. Auf diese Weise wird die Wabe vollständig verbarrikadiert und alle Strukturen abgesichert, die das Nest mit anderen Zweigen verbindet. In einer Untersuchung in Nordthailand überprüfte Seeley et al. (1982) 76 A. florea Nester. Nur 28 von ihnen hatten einen Leimring, bei 24 von ihnen bestand eine Bedrohung durch Oecophylla smaragdina. Das deutet auf ein enge Verknüpfung zwischen der Bedrohung durch die Ameisen und den Klebringen hin. Bisher ist nicht bekannt, wie sich die Präsenz von $O$. smaragdina Ameisen auf die Anlage und den Bau von Leimringen durch $A$. florea auswirkt. In unseren Versuchen wurde eine Weberameise mit einer Pinzette oben auf das A. florea Volk gehalten. Dann wurde die Reaktionen der Bienen auf den Leimring beobachtet. Die Änderung der Bienenzahl an den Ringen und die Gewichtszunahme des Klebharzes wurden bestimmt. Als Kontrolle wurde die Reaktion der Bienen auf eine leere Pinzette, einen Mehlwurm (Larve von Tenebrio molitor) und eine andere baumbewohnende Ameisenart (Crematogaster rogenhoferi) beobachtet.
Wurde eine lebende $O$. smaragdina Arbeiterin dicht über die Wabe von A. florea gehalten, war die Zunahme der Anzahl der Bienen im Bereich der Leimringe im Vergleich zur Kontrolle hoch signifikant (Abb. 1). Die Zahl der Bienen blieb für 2 Stunden auf einem höheren Niveau. Auch wurde hoch signifikant mehr klebriges Material aufgetragen. Die Verstärkung der Leimringe scheint eine spezifische Verhaltensreaktion von A. florea auf ihren bedeutendsten Räuber $O$. smaragdina zu sein. Vergleichbare Verhaltensweisen wurden von Wilson (1975) als Feindspezifikation bezeichnet und für mehrere Ameisenarten beschrieben. Diese Arten erkennen ihre gefährlichsten Feinde und beginnen sofort mit spezifischen Massenangriffen gegen sie zu kämpfen (Hölldobler, 1983). Die Frage über den Erkennungsmechanismus der Weberameisen durch A. florea ist nicht geklärt. Versuche mit $C$. rogenhoferi und den Larven von Tenebrio weisen auf Auslöser hin, die spezifisch für $O$. smaragdina sind.

Apis florea / Oecophylla smaragdina / Volksverteidigung / Räuber-Beute-Beziehung / Crematogaster rogenhoferi

\section{REFERENCES}

Akratanakul P. (1977) The natural history of the dwarf honeybee, Apis florea F., in Thailand, PhD Thesis, Cornell Univ. Ithaca, NY.

Butler C.G. (1954) The world of the honeybee, Collins, London.

Dyer F.C. (1985) Mechanisms of dance orientation in the Asian honeybee Apis florea, J. Comp. Physiol. A $157,183-198$.

Espelie K.E., Gamboa G.J., Grudzien T.A., Bura E.A. (1994) Cuticular hydrocarbons of the paper wasp, Polistes fuscatus - a search for recognition pheromones, J. Chem. Ecol. 20, 1677-1687.

Hölldobler B. (1983) Chemical manipulation, enemy specification and inter-colony communication in ant communities, in: Huber F., Markl H. (Eds.), Neuroethology and Behavioral Physiology, Springer-Verlag Berlin, Heidelberg, pp. 354-365.

Hölldobler B., Wilson E.O. (1983) The evolution of communal nest weaving in ants, Am. Sci. 71, 490 499.

Hölldobler B., Wilson E.O. (1990) The Ants, Springer Verlag, Berlin.

Koeniger N., Fuchs S. (1973) Sound production as colony defense in Apis cerana Fabr., Proc. VII Congr. IUSSI, London, pp. 199-203.

Koeniger N., Fuchs S. (1975) Zur Kolonieverteidigung der asiatischen Honigbienen, Z. Tierpsychol. 37, 99-106. 
Koeniger N., Koeniger G., Punchihewa R.K.W Fabritius Mo., Fabritius Mi. (1982) Observations and experiments on dance communication in Apis florea in Sri Lanka, J. Apic. Res. 21, 45-52.

Lindauer M. (1956) Über die Verständigung bei indischen Bienen, Z. Vgl. Physiol. 34, 299-345.

Meyer W. (1954) Die "Kittharzbienen" und ihre Tätigkeiten, Z. Bienenforsch. 5, 185-200.

Pirk C.W.W., Hepburn R., Radloff S.E., Erlandsson J. (2002) Defense posture in the dwarf honeybee, Apis florea, Apidologie 33, 289-294.

Seeley T.D. (1983) The ecology of temperate and tropical honeybee societies, Am. Sci. 71, 264-272.

Seeley T.D. (1985) Honeybee ecology. A study of adaptation in social life. Monographs in Behavior and Ecology, Princeton University Press, Princeton, New Jersey, USA.
Seeley T.D., Seeley R., Akratanakul P. (1982) Colony defense strategies of the honeybees in Thailand, Ecol. Monogr. 52, 43-63.

Sen Sarma M., Fuchs S., Tautz J. (2000) Debris removal by head pushing in Apis florea F. honeybees, Naturwissenschaften 87, 241-243.

Sen Sarma M., Fuchs S., Werber C., Tautz J. (2002) Worker piping triggers hissing for coordinated colony defence in the dwarf honeybee Apis florea, Zoology 105, 215-223.

Wilson E.O. (1971) The Insect Societies, Harvard University Press, Cambridge, Mass.

Wilson E.O. (1975) Enemy specification in the alarmrecruitment system of an ant, Science 190, 798800

Wongsiri S. (1989) The effects of the import of Apis mellifera L. to Thailand, Proc. 4th Int. Conf. Apic. Tropical Climates, Cairo 1988, pp. 162-167. 